\title{
Comparison of hydrological models in upper Aras Basin
}

\section{Yukarı Aras Havzasında hidrolojik modellerin karşıllaștırması}

\author{
Ali Arda SORMAN ${ }^{1}$ (D) Emin TAS $^{*}$ (D), YusufOgulcan DOGAN ${ }^{3}$ \\ 1,3Department of Civil Engineering, Engineering Faculty, Eskişehir Technical University, Eskişehir, Turkey. \\ asorman@eskisehir.edu.tr, fbogulcan06@gmail.com \\ ${ }^{2}$ Department of Civil Engineering, Engineering Faculty, Afyon Kocatepe University, Afyonkarahisar, Turkey.
} emintas@aku.edu.tr

\section{Abstract}

The increasing importance of water resources planning and management each day has led to a widespread use of hydrologic modeling. Especially in Turkey, where the headwaters of drainage basins are located around mountainous areas, snowmelt dominates streamflow during spring months which makes modeling applications important and necessary. In this study, two different conceptual hydrologic models (HEC-HMS and HBV) are compared during 2008-2015 water years in the mountainous headwaters of Aras Basin, located in eastern Turkey. For both models, performance on runoff using Nash-Sutcliffe Efficiency is above 0.8 and 0.7 for calibration and validation respectively. This first conceptual hydrologic modeling implementation and comparison in Aras Basin did indeed give promising results as well as suggesting to consider other variables beside streamflow.

Keywords: Hydrologic modeling, HEC-HMS, HBV, Snow water equivalent, Aras basin.

\section{Introduction}

Millions of people will be exposed to increasing water stress and floods with growing population and changing climate/land use patterns throughout the world in the coming decades. Hence, effective management of water resources is an increasingly important issue [1]. For prediction of land use and climate change effects on water resources, most applications of hydrological design and forecasting require the use of hydrologic models [2]. Assessments of the hydrologic impacts are required for developing strategies to cope with changing conditions, which is often approached using hydrological models in combination with climate scenarios. River flow in highlands is essential for irrigation, hydropower generation, and sustaining ecosystems that depend directly or indirectly on snow melting. Snow melt is crucial for water supply hence, it is of great concern for water management especially in mountainous basins [3].

In this study, HEC-HMS (Hydrologic Engineering Center Hydrologic Modeling System) and HBV (Hydrologiska Byrans Vattenbalansavdelning) physically based conceptual hydrological models, including continuous snow and soil moisture accounting algorithms are applied in the upper Aras

\footnotetext{
${ }^{*}$ Corresponding author/Yazıșllan Yazar
}

Öz

Günbegün önemi artan su kaynaklarl planlama ve yönetimi çalışmalarında hidrolojik modellemenin etkin kullanılması yaygınlaşmaktadır. Özellikle Türkiye'deki drenaj havzaları bașlangıc bölgelerinin karlı dağlık alanlardan olușması ve bahar aylarında karların erimesiyle birlikte akımların büyük bir bölümünün kar erimesinden meydana gelmesi bu bölgelerdeki modelleme uygulamalarını önemli ve zorunlu kılmaktadır. Bu çalışmada, Türkiye'nin doğu ve dağllk bölgesinde yer alan Aras Havzasının memba sularl iki farklı kavramsal hidrolojik model (HEC-HMS ve HBV) kullanilarak 2008-2015 su yılları arasında modellenmiș ve karșılaștırılmıștır. Nash-Sutcliffe ölçütü kullanılarak performansı değerlendirilen her iki modelin akıma göre kalibrasyon başarısı 0.8 ve doğrulaması 0.7 değerlerinin üzerinde bulunmuștur. Aras Havzasında öncül bir kavramsal hidrolojik modelleme uygulamass olan bu karșılaștırma çalıșmasının bașarılı sayılabilecek sonuçlar verdiği ve benzer çalıșmaların akımın yanı sıra bașka değișkenlerin de çalıșmaya dahil edilebileceğini göstermiștir.

Anahtar kelimeler: Hidrolojik modelleme, HEC-HMS, HBV, Kar su eșdeğeri, Aras havzası.

River Basin, located in the mountainous eastern Turkey where optimum operation and management of water resources is a vital task. The processes of model development, parameterization, calibration and validation are described, and results of HEC-HMS and HBV models are compared with each other considering runoff and snow measurements.

Although several studies on HEC-HMS Soil Moisture Accounting (SMA) [4] modeling are practiced in different countries, this is the first study in Turkey. HEC-HMS SMA is performed to simulate and forecast streamflow in various parts of the world by many researchers [5]-[12]. In the recent years, some investigators analyzed the use of different automatic calibration methods applied to HEC-HMS [13]-[15]. Additional studies concentrated on comparing different modules

HEC-HMS with other hydrologic models such as MIKE-SHE [16], LBRM [17]-[18] and artificial neural networks [19]-[20] achieving successful results.

Hydrological modeling using HBV [21] is conducted more than 90 countries in the world [22], including Turkey, but this is the first application in Aras River Basin. Some of the studies that applied HBV model in different versions are on sensitivity and parameter uncertainty analysis [23]-[25], regionalization of model parameters [26]-[28], flood analysis [29], multiobjective calibration [30]-[35] and climate change [36]-[38]. 
HBV model is also evaluated in comparison to other hydrological models such as SRM [39]-[40], VIC model [41], SWIM and artificial neural networks [42]. Until recently, a limited number of hydrological model applications considering both HEC-HMS SMA and HBV are documented in literature [43]-[45] with this being the first in Turkey.

The main objective of this paper is to show the applicability of different conceptual hydrologic models in a mountainous area of Turkey which is complex in terms of climate, topography and data. In addition to this, a pioneer modeling study is performed as a source of motivation for future studies in the Aras River Basin where large dams for energy production and irrigation are planned.

\section{Material and methods}

\subsection{Study area}

Kayabasi Basin with a stream gauging station D24A096 (39:50:16N-41:50:19E) located at the headwaters of Aras River in eastern Turkey (Figure 1) is selected as the study area. The basin has an area of $2758 \mathrm{~km}^{2}$ with a mean slope of $19.6 \%$. Elevation ranges from 1659 to $3187 \mathrm{~m}$ with a hypsometric mean of $2218 \mathrm{~m}$. The main land cover types are grassland/pasture (50.4\%), bare land (30.8\%) and agricultural area $(15 \%)$. The basin is quite mountainous therefore, snow plays a significant role in the hydrologic cycle.

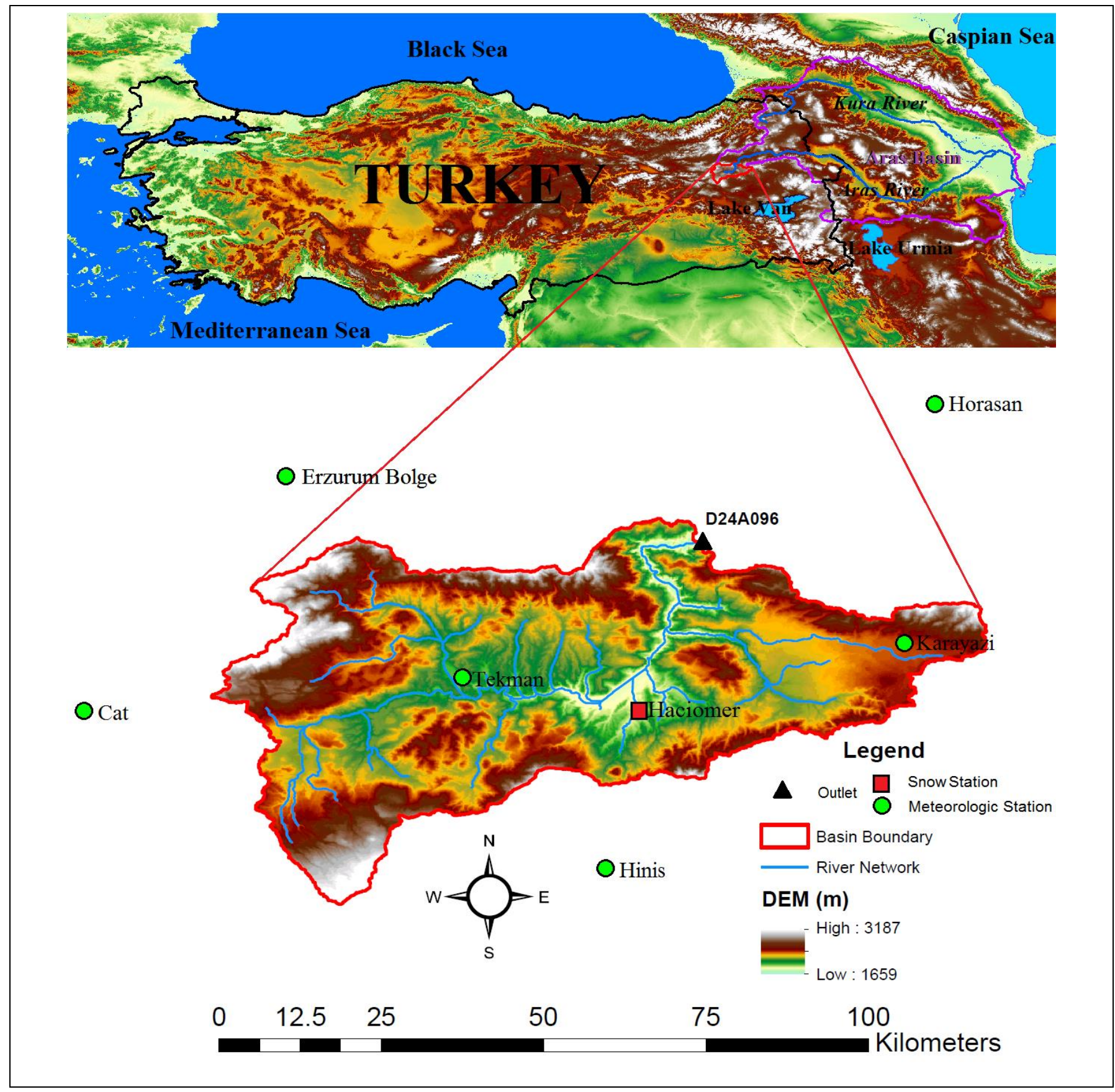

Figure 1. Geographical position and DEM of Kayabasi Basin. 
Meteorological data is obtained from 6 meteorological observation stations located in the vicinity of Kayabasi Basin (Figure 1). Hydro-meteorological conditions of the basin are presented in Figure 2, where the annual mean precipitation $(\mathrm{P})$ is around $450 \mathrm{~mm}$ and the annual mean temperature $(\mathrm{T})$ is $7{ }^{\circ} \mathrm{C}$. The average discharge (Q) of Kayabasi stream gauging station is $20.6 \mathrm{~m}^{3} / \mathrm{s}(235 \mathrm{~mm})$ which has observations since 2008 and a maximum observed streamflow of $383 \mathrm{~m}^{3} / \mathrm{s}$ [46]. In accordance to the monthly mean discharge values at the station, snowmelt contributes roughly $76.5 \%$ of total annual runoff volume during the melt season (spring and early summer months). Being located on a transboundary region and having a high snow potential at the headwaters of Aras River, Kayabasi Basin is a crucial area to operate hydrologic models in the future for a more effective water resources management.

\subsection{Hydrological models}

\subsubsection{HEC-HMS model}

HEC-HMS, formerly known as HEC-1 and developed in 1998 by United States Army Corps of Engineers-Hydrologic Engineering Center (USACE-HEC) is a conceptual model that simulates hydrological process as continuous or event based. In this paper, SMA module considering continuous situation based soil moisture variation is carried out that calculates the amount of water stored in and moving through vegetation, soil surface, profile and groundwater layers [4].
Inputting precipitation, temperature and potential evapotranspiration data into the model, SMA computes surface runoff, groundwater flow, losses due to evapotranspiration/infiltration, soil moisture, snow water equivalent and deep percolation over the entire basin using elevation zones. The SMA model represents the watershed with a series of storage layers, as illustrated by Figure 3(a). Rates of inflows to, outflows from, and capacities of these layers control the volume of water lost or accumulated in these storage components. Current storage contents are calculated during the simulation and vary continuously both during and between storms [47].

\subsubsection{HBV model}

HBV is a conceptual and continuous hydrological model Figure 3(b) created in 1972 by Swedish Meteorological and Hydrological Institute (SMHI) for forecasting the inflow to reservoirs and flood warning. Many different versions of the HBV model are used worldwide. The model used in this study is the HBV-Light version developed by [48] that has userfriendly graphical interface and automatic calibration option.

HBV model distributes precipitation, temperature and potential evapotranspiration inputs based on elevation and vegetation zones. The model simulates daily flow by calculating the snow and soil moisture layers based on zones, the runoff and routing processes based on the whole basin.

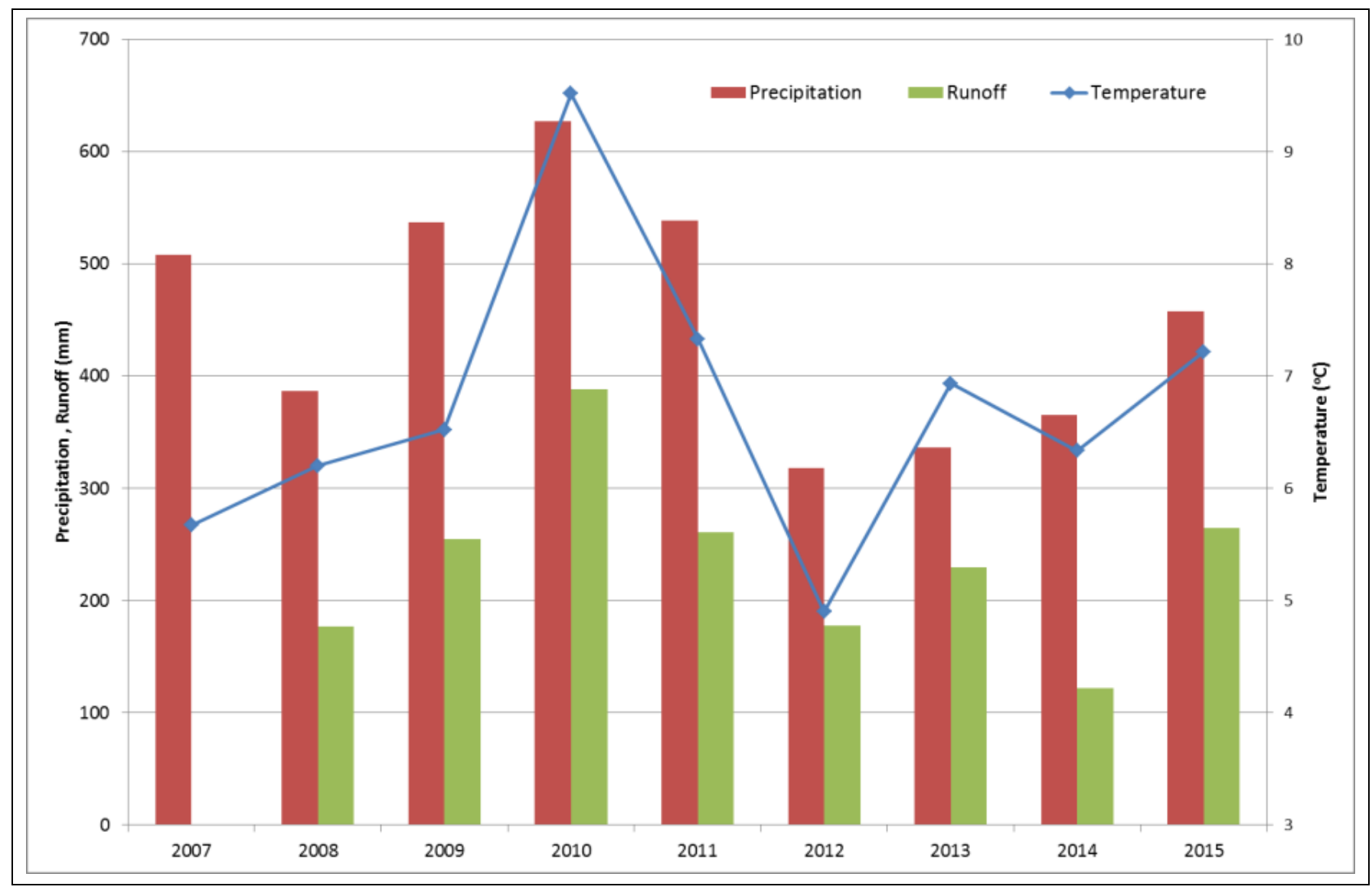

Figure 2. Hydro-meteorological conditions of Kayabasi Basin. 


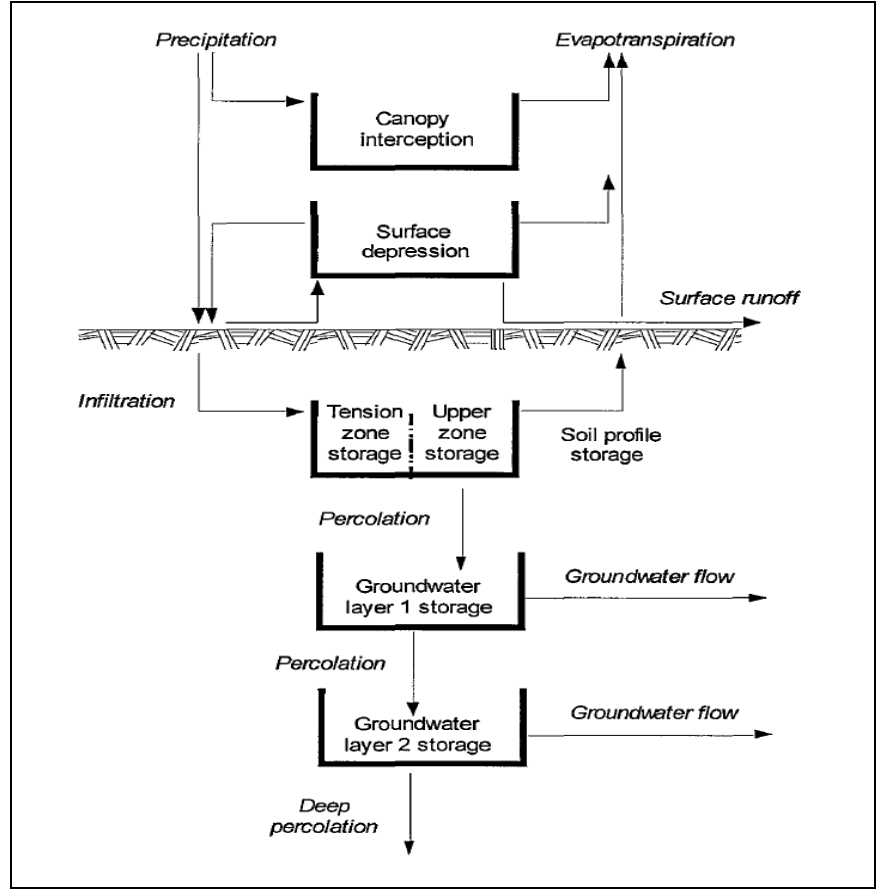

(a): HEC-HMS SMA model [4].

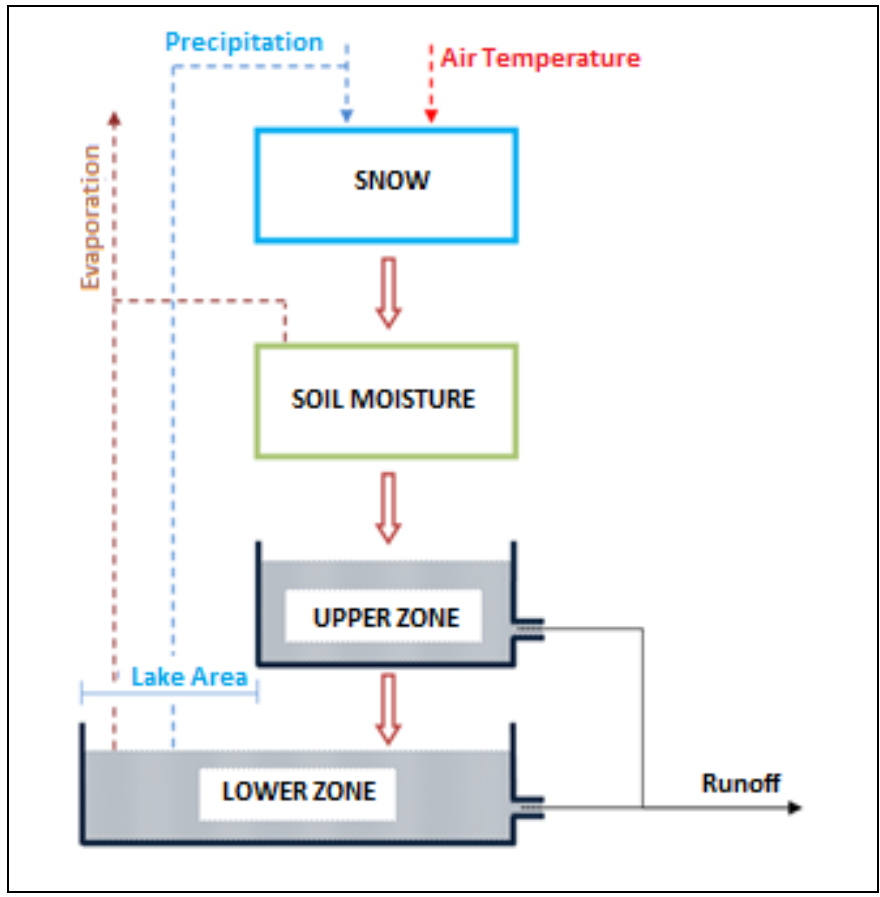

(b): HBV model [49].

Figure 3. Hydrological models used in the study.

\section{Results}

In this study, 8-year period flow data of Kayabasi stream gauging station (D24A096) from 1 October 2007 to 30 September 2015 (2008-2015 water years) are used for hydrological modeling. In addition, 2007 water year meteorological data are used to warm up the models. Application period is divided into two separate parts of 4 years for model calibration and validation. Firstly, parameters for both models are manually adjusted by taking into consideration the discharge values only. Afterwards, by setting allowable ranges for the model parameters, automatic calibration is carried out using Genetic Algorithm method in HBV model and Nelder-Mead method in HEC-HMS model. Final parameters are given in Table 1. To measure the success of the model results, Nash-Sutcliffe Efficiency (NSE) criterion [50], commonly used in the literature and given in Equation 1 is utilized. The NSE criterion ranges from- $\infty$ to 1 , with 0 representing average flow success.

$$
\begin{gathered}
N S E=1-\frac{\sum\left(Q_{O}-Q_{M}\right)^{2}}{\sum\left(Q_{O}-\overline{Q_{O}}\right)^{2}} \\
Q_{O}=\text { Observed discharge } \\
Q_{M}=\text { Modeled discharge } \\
\overline{Q_{O}}=\text { Observed mean discharge }
\end{gathered}
$$

In each modeling case, initially 2008-2011 water years are treated as calibration and 2012-2015 years as validation periods. Then by applying a split sample test, these cal/val periods are shifted (2012-2015 calibration, 2008-2011 validation) to check the data variability for different years. Model runoff and snow water equivalent results are depicted in Figure 4 and Figure 5 respectively. Overall model performance results are summarized in Table 2 .
When the modeling results are considered, performance of both models can be accepted as successful with calibration scores above 0.81 and validation above 0.70 according to the NSE benchmark [51]. After the split sample test, there is no significant change in the model performance meaning that the model can produce successful results even with different inputs. While HEC-HMS model gives similar values for the calibration and validation criteria, HBV model yields more successful calibration but slightly lower validation results. A reason for this could be attributed to automatic optimization algorithm of HBV where model parameters are forced to match the high flows more than the low values considering NSE. When runoff values are compared graphically (Figure 4), HEC-HMS model responds quicker to runoff peaks while HBV model underestimates the observed low flow values most probably due to quick drying up of the soil layer. Evaluating the snow water equivalent (SWE) output of both models (Figure 5), HBV tends to accumulate more snow within the basin. Fortunately, there is an in-situ manual snow site conducted at Haciömer station (1865 m) (Figure 1) within Kayabasi Basin which is located at a lower altitude than the basin hypsometric mean. When ground point SWE measurements are compared with basin average model results, the increasing trend during the snow accumulation, timing of near to maximum SWE and decreasing trend in the depletion phase can easily be detected. Due to the varying number of in-situ SWE observations, more measurements on the accumulation period than the depletion part, as well as 12 measurements between 2008-2011 seasons compared to 22 in 2012-2015 years, calculating a SWE performance would be biased. Hence for SWE, visual trend and timing comparison is found to be reasonable enough. Therefore, it can be stated that while HEC-HMS model accumulates slightly lower snow within the basin, it produces similar runoff values with HBV model. 
Table 1. Model parameters.

\begin{tabular}{|c|c|c|c|c|c|}
\hline \multicolumn{3}{|c|}{ HBV Parameters } & \multicolumn{3}{|c|}{ HEC HMS Parameters } \\
\hline $\begin{array}{c}\text { TCALT } \\
\text { (gradient parameter for } \\
\text { temperature) }\end{array}$ & ${ }^{\circ} \mathrm{C} / 100 \mathrm{~m}$ & 0.485 & $\begin{array}{c}\text { Lapse Rate } \\
\text { (temperature adjustment with } \\
\text { respect to elevation) }\end{array}$ & ${ }^{\circ} \mathrm{C} / 1000 \mathrm{~m}$ & -6.9 \\
\hline $\begin{array}{c}\text { PCALT } \\
\text { (gradient parameter for } \\
\text { precipitation) }\end{array}$ & $\% / 100 \mathrm{~m}$ & 3.521 & $\begin{array}{l}\text { Index } \\
\text { (precipitation adjustment with } \\
\text { respect to elevation) }\end{array}$ & $\mathrm{mm} / 1000 \mathrm{~m}$ & 10.0 \\
\hline $\begin{array}{c}\text { TT } \\
\text { (threshold temperature for snowfall) }\end{array}$ & ${ }^{\circ} \mathrm{C}$ & 0.123 & $\begin{array}{c}\text { PX Temperature } \\
\text { (rain/snow temperature) }\end{array}$ & ${ }^{\circ} \mathrm{C}$ & 2.686 \\
\hline $\begin{array}{c}\text { CFMAX } \\
\text { (degree day factor) }\end{array}$ & $\begin{array}{l}\mathrm{mm} / \text { day } \\
{ }^{\circ} \mathrm{C}\end{array}$ & 4.727 & $\begin{array}{c}\text { Base Temperature } \\
\text { (snow melt temperature) }\end{array}$ & ${ }^{\circ} \mathrm{C}$ & 0.797 \\
\hline $\begin{array}{c}\text { CWH } \\
\text { (water holding capacity of snow) }\end{array}$ & - & 0.1 & $\begin{array}{l}\text { ATI-Meltrate Function } \\
\text { (meltrate of snowpack) }\end{array}$ & $\mathrm{mm} /$ day $^{\circ} \mathrm{C}$ & $0.0-7.5$ \\
\hline $\begin{array}{c}\mathrm{FC} \\
\text { (max soil storage) }\end{array}$ & $\mathrm{mm}$ & 338.1 & $\begin{array}{c}\text { Water Capacity } \\
\text { (water holding capacity in } \\
\text { snowpack) }\end{array}$ & $\%$ & 13.3 \\
\hline $\begin{array}{c}\text { LP } \\
\text { (limit for potential } \\
\text { evapotranspiration) }\end{array}$ & - & 0.886 & Max Infiltration & $\mathrm{mm} / \mathrm{hr}$ & 2.05 \\
\hline $\begin{array}{c}\text { BETA } \\
\text { (shape coefficient) }\end{array}$ & - & 1.911 & $\begin{array}{l}\text { Tension Storage } \\
\text { (soil zone prone to } \\
\text { evapotranspiration) }\end{array}$ & $\mathrm{mm}$ & 50.0 \\
\hline $\begin{array}{c}\text { PERC } \\
\text { (max percolation) }\end{array}$ & $\mathrm{mm} /$ day & 3.365 & Soil Storage & $\mathrm{mm}$ & 75.0 \\
\hline $\begin{array}{c}\text { UZL } \\
\text { (threshold parameter for extra } \\
\text { outflow from upper zone) }\end{array}$ & $\mathrm{mm}$ & 19.0 & Time of Concentration & $\mathrm{hr}$ & 6 \\
\hline $\begin{array}{c}\text { K0 } \\
\text { (upper store recession coefficient) }\end{array}$ & $1 /$ day & 0.500 & $\begin{array}{c}\text { Storage Coefficient } \\
\text { (time lag for transforming water } \\
\text { in storage to become lateral } \\
\text { outflow) }\end{array}$ & $\mathrm{hr}$ & 250 \\
\hline$\frac{\mathrm{K} 1}{\text { (middle store recession coefficient) }}$ & 1/day & 0.101 & Ground Water 1 Storage & $\mathrm{mm}$ & 0.3 \\
\hline $\begin{array}{c}\mathrm{K} 2 \\
\text { (lower store recession coefficient) }\end{array}$ & 1/day & 0.047 & Ground Water 2 Storage & $\mathrm{mm}$ & 40.0 \\
\hline
\end{tabular}

Table 2. NSE model runoff performance results for calibration and validation periods.

\begin{tabular}{ccccc}
\hline \multirow{2}{*}{ Model } & $2008-2011$ & $2012-2015$ & $2008-2011$ & $2012-2015$ \\
& Calibration & Validation & Validation & Calibration \\
\hline HEC-HMS & 0.82 & 0.78 & 0.83 & 0.81 \\
HBV & 0.86 & 0.72 & 0.70 & 0.88 \\
\hline
\end{tabular}

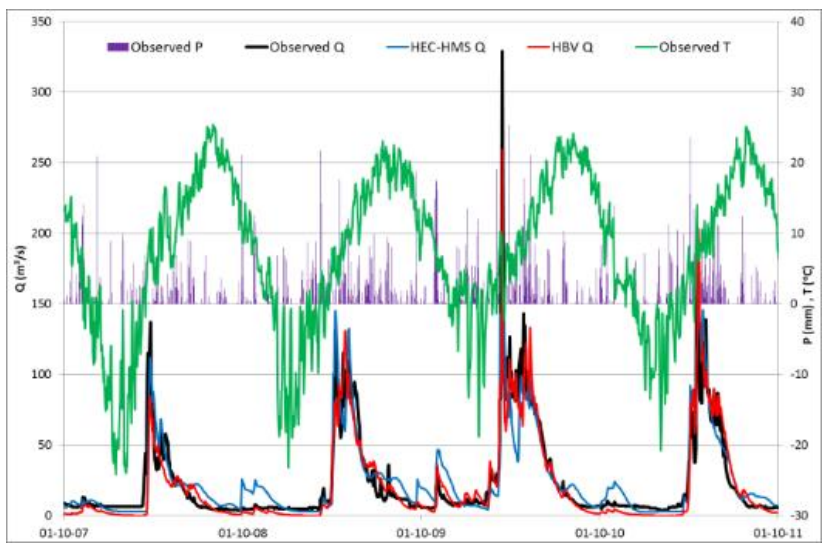

(a): 2008-2011 calibration period.

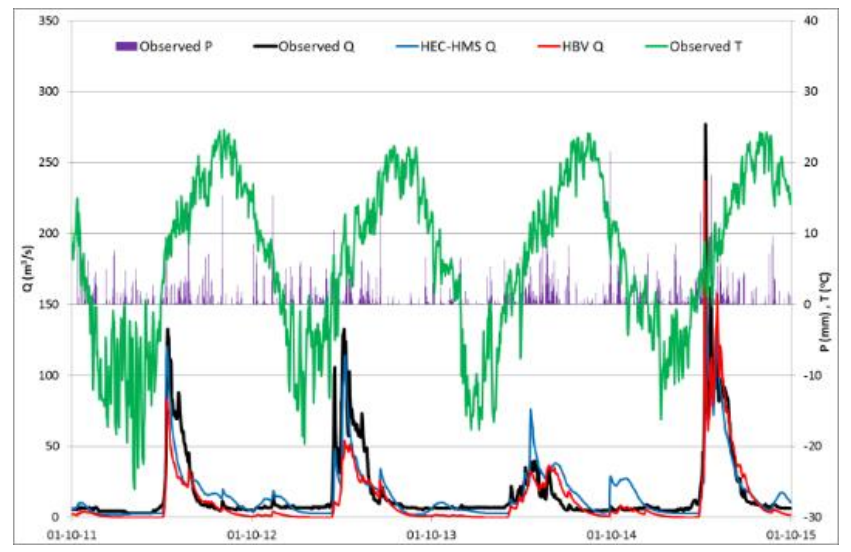

(b): 2012-2015 validation period.

Figure 4. Model runoff results. 


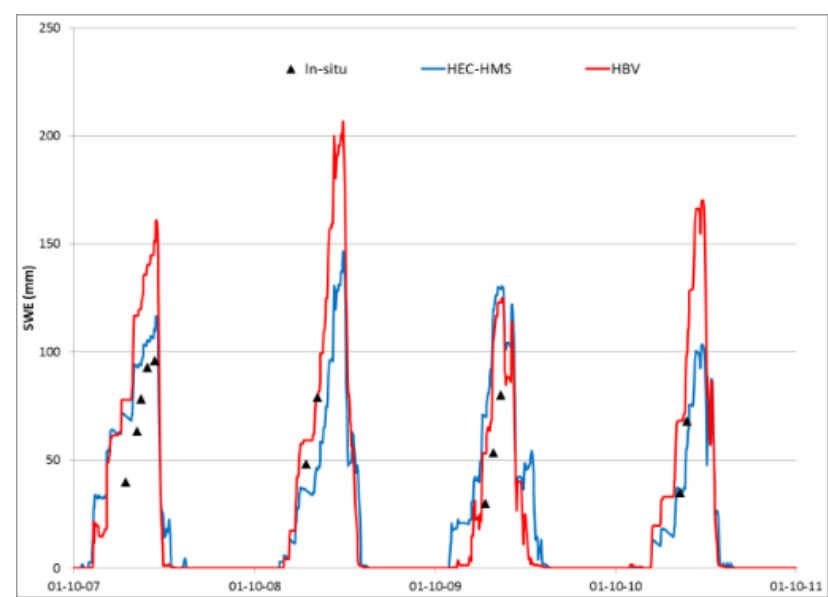

(a): 2008-2011 calibration period.

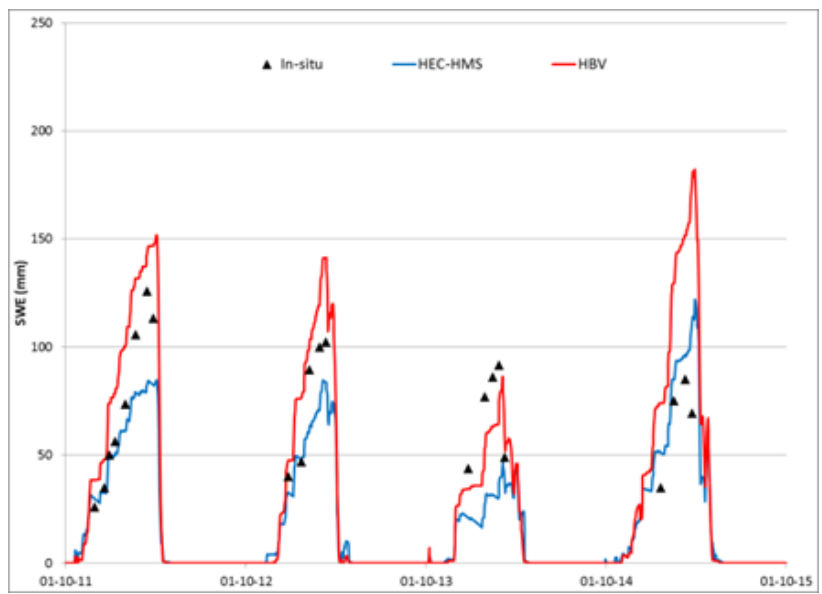

(b): 2012-2015 validation period.

Figure 5. Model snow water equivalent (SWE) results.

\section{Conclusion}

In this study, a hydrological multi-modeling application is presented in the upstream part of Aras River which is a transboundary water resource rising from the high elevations of eastern Turkey. Within the considered area of interest, no conceptual hydrological modeling study has been carried out before whereas on the other hand, crucial hydraulic structures are being planned for the near future. This situation increases the value of the research.

In the framework of multi-model approach, two different conceptual hydrological models (HEC-HMS and HBV) are set through calibration/validation processes using 8-year hydrometeorological data in the pilot basin. Both models presented similar successful results in terms of runoff performance while behaving a little differently in the snow output. In hydrological modeling, it is crucial to match the end product runoff values as well as the internal states of the model. Therefore, comparing model results with different in-situ measurements is very valuable for model reliability.

In mountainous eastern regions of Turkey, snowmelt induced runoff generates approximately $2 / 3$ of the total annual flow volume in spring and early summer months [52]-[53]. For this reason, it is important in such areas to have a dense hydrometeorological gauge network as well as accessibility to realtime data. In the recent years, governmental institutes are working very hard to increase the automatic gauge network density especially in the elevated areas. Therefore, future research on the region will concentrate more on multi-model (comparing different model results) as well as multi-criteria (multiple performance measures) modeling using up-to-date ground measurements and areal remote sensing data.

\section{Acknowledgement}

This study is supported by Eskişehir Technical University Scientific Research Project BAP1705F122. Hydrometeorological data used in the modeling analysis is provided by Turkish State Meteorological Service and State Hydraulic Works.

\section{References}

[1] Vörösmarty CJ, McIntyre PB, Gessner MO, Dudgeon D, Prusevich A, Green P, Glidden S, Bunn SE, Sullivan CA, Liermann CR, Davies PM. "Global threats to human water security and river biodiversity". Nature, 467(7315), 555-561, 2010.

[2] Dingman SL. Physical Hydrology. USA, Waveland Press, Inc., 2002.

[3] Duethmann D, Peters J, Blume T, Vorogushyn S, Güntner A. "The value of satellite-derived snow cover images for calibrating a hydrological model in snow-dominated catchments in Central Asia". Water Resources Research, 50, 2002-2021, 2014.

[4] Bennett TH. Development and Application of a Continuous Soil Moisture Accounting Algorithm for the Hydrologic Engineering Center Hydrologic Modeling System (HEC-HMS). MSc Thesis, University of California, Davis, USA, 1998.

[5] Fleming M, Neary V. "Continuous hydrologic modeling study with the Hydrologic Modeling System". Journal of Hydrologic Engineering, 9(3), 175-183, 2004.

[6] Garcia A, Sainz A, Revilla JA, Alvarez C, Juanes JA, Puente A. "Surface water resources assessment in scarcely gauged basins in the north of Spain". Journal of Hydrology, 356, 312-326, 2008.

[7] Rahimi M, Saghafian B, Azadi M, Sedgi H. "Flood forecasting in arid and semi arid region using continuous hydrological modeling". World Applied Sciences Journal, 10(6), 645-654, 2010.

[8] Roy D, Begam S, Ghosh S, Jana S. "Calibration and validation of HEC-HMS model for a river basin in Eastern India". ARPN Journal of Engineering and Applied Sciences, 8(1), 40-56, 2013.

[9] Koch R, Bene K. "Continuous hydrologic modeling with HMS in the Aggtelek Karst region". Hydrology, 1(1), 1-7, 2013. 
[10] Singh WR, Jain MK. "Continuous hydrological modeling using soil moisture accounting algorithm in Vamsadhara River Basin, India". Journal of Water Resource and Hydraulic Engineering, 4(4), 398-408, 2015.

[11] Gebre SL. "Application of the HEC-HMS model for runoff simulation of Upper Blue Nile River Basin". Hydrology: Current Research, 6(2), 1-8, 2015.

[12] Bhuiyan HAKM, McNairn H, Powers J, Merzouki A. "Application of HEC-HMS in a cold region watershed and use of RADARSAT-2 soil moisture in initializing the model”. Hydrology, 4(1), 9, 1-19, 2017.

[13] Mousavi SJ, Abbaspour KC, Kamali B, Amini M, Yang H. "Uncertainty-based automatic calibration of HEC-HMS model using sequential uncertainty fitting approach". Journal of Hydroinformatics, 14, 286-309, 2012.

[14] Kamali B, Mousavi SJ, Abbaspour KC. "Automatic calibration of HEC-HMS using single-objective and multi-objective PSO algorithms". Hydrological Processes, 27, 4028-4042, 2013.

[15] Dariane AB, Javadianzadeh MM, James LD. "Developing an efficient auto-calibration algorithm for HEC-HMS program". Water Resources Management, 30(6), 1923-1937, 2016.

[16] Meselhe EA, Habib EH, Oche OC, Gautam S. "Sensitivity of conceptual and physically based hydrologic models to temporal and spatial rainfall sampling". Journal of Hydrologic Engineering, 14(7), 711-720, 2009.

[17] Yilmaz AG, Imteaz MA, Ogwuda O. "Accuracy of HEC-HMS and LBRM models in simulating snow runoffs in Upper Euphrates Basin". Journal of Hydrologic Engineering, 17(2), 342-347, 2012.

[18] Gyawali R, Watkins DW. "Continuous hydrologic modeling of snow-affected watersheds in the Great Lakes Basin using HEC-HMS". Journal of Hydrologic Engineering, 18(1), 29-39, 2013.

[19] Rezaeianzadeh M, Stein A, Tabari H, Abghari H, Jalalkamali N, Hosseinipour EZ, Singh VP. "Assessment of a conceptual hydrological model and artificial neural networks for daily outflows forecasting". International Journal Environmental Science and Technology, 10(6), 1181-1192, 2013.

[20] Ayvaz MT, Tezel U, Kentel E, Goktas RK. "Weekly flow prediction of Ergene River using an artificial neural network based solution approach". EPiC Series in Engineering-HIC 2018: 13 th International Conference on Hydroinformatics, 3, 155-161, 2018.

[21] Bergström S. "Development and Application of a Conceptual Runoff Model for Scandinavian Catchments". SMHI, Norrköping, Sweden, SMHI Report Hydrologi Och Oceanografi Nr RHO 7, 1976.

[22] Bergström S, Lindström G. "Interpretation of runoff processes in hydrological modelling-experience from the HBV approach". Hydrological Processes, 29, 3535-3545, 2015.

[23] Seibert J. "Estimation of parameter uncertainty in the HBV model". Nordic Hydrology, 28(4/5), 247-262, 1997.

[24] Parajka J, Merz R, Blöschl G. "Uncertainty and multiple objective calibration in regional water balance modelling: Case study in 320 Austrian catchments". Hydrological Processes, 21(4), 435-446, 2007.

[25] Abebe NA, Ogden FL, Pradhan NR. "Sensitivity and uncertainty analysis of the conceptual HBV rainfallrunoff model: Implications for parameter estimation". Journal of Hydrology, 389, 301-310, 2010.
[26] Seibert J. "Regionalisation of parameters for a conceptual rainfall-runoff model". Agricultural and Forest Meteorology, 98-99, 279-293, 1999.

[27] Parajka J, Merz R, Blöschl G. "A comparison of regionalisation methods for catchment model parameters". Hydrology and Earth System Sciences, 5, 157-171, 2005.

[28] Beck HE, van Dijk AIJM, de Roo A, Miralles DG, McVicar TR, Schellekens J, Bruijnzeel LA. "Global-scale regionalization of hydrologic model parameters". Water Resources Research, 52, 3599-3622, 2016.

[29] Grillakis MG, Tsanis IK, Koutroulis AG. "Application of the HBV hydrological model in a flash flood case in Slovenia". Natural Hazards and Earth System Sciences, 10, 2713-2725, 2010.

[30] Seibert J. "Multi-criteria calibration of a conceptual runoff model using a genetic algorithm". Hydrology and Earth System Sciences, 4(2), 215-224, 2000.

[31] Bergström S, Lindström G, Pettersson A. "Multi-variable parameter estimation to increase confidence in hydrological modeling". Hydrological Processes, 16, 413-421, 2002.

[32] Udnaes HC, Alfnes E, Andreassen LM. "Improving runoff modelling using satellite-derived snow covered area". Nordic Hydrology, 38(1), 21-32, 2007.

[33] Parajka J, Blöschl G. "The value of MODIS snow cover data in validating and calibrating conceptual hydrologic models". Journal of Hydrology, 358(3-4), 240-258, 2008.

[34] Sorman AA, Sensoy A, Tekeli AE, Sorman AU, Akyurek Z. "Modeling and forecasting snowmelt runoff process using the HBV model in the eastern part of Turkey". Hydrological Processes, 23, 1031-1040, 2009.

[35] Finger D, Vis M, Huss M, Seibert J. "The value of multiple data set calibration versus model complexity for improving the performance of hydrological models in mountain catchments". Water Resources Research, 51, 1939-1958, 2015.

[36] Driessen TLA, Hurkmans RTWL, Terink W, Hazenberg P, Torfs PJJF, Uijlenhoet R. "The hydrological response of the Ourthe catchment to climate change as modelled by the HBV model". Hydrology and Earth System Sciences, 14, 651-665, 2010.

[37] Bhattarai S, Zhou Y, Shakya NM, Zhao C. "Hydrological modelling and climate change impact assessment using HBV light model: A case study of Narayani River Basin, Nepal". Nature Environment and Pollution Technology, 17(3), 691-702, 2018.

[38] Vozinaki AEK, Tapoglou E, Tsanis IK. "Hydrometeorological impact of climate change in two Mediterranean basins". International Journal of River Basin Management, 16(2), 245-257, 2018.

[39] Ferguson RI. "Snowmelt runoff models". Progress in Physical Geography, 23(2), 205-227, 1999.

[40] Sorman AA, Sensoy A, Yamankurt E, Gozel E. “A comparison of SRM and HBV models for real time runoff forecasting in the Upper Euphrates Basin, Turkey". Geophysical Research Abstracts, 14, EGU2012-780, 2012.

[41] te Linde AH, Aerts JCJH, Hurkmans RTWL, Eberle M. "Comparing model performance of two rainfall-runoff models in the Rhine basin using different atmospheric forcing data sets". Hydrology and Earth System Sciences, 12, 943-957, 2008. 
[42] Gao C, Yao MT, Wang YJ, Zhai JQ, Buda S, Fischer T, Zeng $\mathrm{XF}$, Wang WP. "Hydrological model comparison and assessment: criteria from catchment scales and temporal resolution". Hydrological Sciences Journal, 61(10), 1941-1951, 2016.

[43] Grillakis MG, Koutroulis AG, Tsanis IK. "Climate change impact on the hydrology of Spencer Creek watershed in Southern Ontario, Canada". Journal of Hydrology, 409, 1-19, 2011.

[44] Plesca I, Timbe E, Exbrayat JF, Windhorst D, Kraft P, Crespo P, Vache KB, Frede HG, Breuer L. "Model intercomparison to explore catchment functioning: Results from a remote montane tropical rainforest". Ecological Modelling, 239, 3-13, 2012.

[45] Yaghoubi M, Massah Bavani AR. "Sensitivity analysis and comparison of capability of three conceptual models HEC-HMS, HBV and IHACRES in simulating continuous rainfall-runoff in semi-arid basins". Journal of the Earth and Space Physics, 40(2), 153-172, 2014.

[46] Devlet Su İșleri. "SVT Rasatlar Bilgi Bankası". http://svtbilgi.dsi.gov.tr/Bilgi.aspx?istasyon=D24A096\% 20KAYABA\%C5\%9EI\%20ARAS\%20N (07.05.2019).

[47] USACE (US Army Corps of Engineers). "Hydrologic Modeling System HEC-HMS Technical Reference Manual". Hydrologic Engineering Center, Davis, USA, 2000.
[48] Seibert J, Vis MJP. "Teaching hydrological modeling with a user-friendly catchment-runoff-model software package". Hydrology and Earth System Sciences, 16, 3315-3325, 2012.

[49] Killingtveit A, Saelthun NR. Hydrology, Hydropower Development, Trondheim, Norway, Norwegian Institute of Technology, 1995.

[50] Nash JE, Sutcliffe JV. "River flow forecasting through conceptual models. Part I-A discussion of principles". Journal of Hydrology, 10(3), 282-290, 1970.

[51] Moriasi DN, Arnold JG, Van Liew MW, Binger RL, Harmel RD, Veith TL. "Model evaluation guidelines for systematic quantification of accuracy in watershed simulations". Transactions of the ASABE, 50(3), 885-900, 2007.

[52] Altinbilek D. "Development and management of the Euphrates-Tigris Basin". International Journal of Water Resources Development, 20(1), 15-33, 2004.

[53] Tekeli AE, Akyürek Z, Șorman AA, Șensoy A, Sorman AU. "Using MODIS snow cover maps in modeling snowmelt runoff process in the eastern part of Turkey". Remote Sensing of Environment, 97, 216-230, 2005. 